\title{
NARODNA KNJIŽNICA KAO DRUŠTVENI SVJETIONIK U VREMENU BOLESTI COVID-19
}

\author{
PUBLIC LIBRARY \\ AS A SOCIAL BEACON IN TIME OF COVID-19
}

\author{
Radovan Vrana \\ Odsjek za informacijske i komunikacijske znanosti \\ Filozofski fakultet, Sveučilište u Zagrebu \\ rvrana@ffzg.hr \\ Jasna Kovačević \\ Knjižnica i čitaonica Bogdana Ogrizovića \\ Knjižnice grada Zagreba \\ jasna.kovacevic@kgz.hr
}

UDK / UDC 027.022:616.2-044.372(497.5 Zagreb)

Izvorni znanstveni rad / Original scientific paper

Primljeno / Received: 7. 12. 2020.

Prihvaćeno / Accepted: 27. 1. 2021.

\section{Sažetak}

Cilj. Cilj je predstaviti rezultate istraživanja korisnika Knjižnice i čitaonice Bogdana Ogrizovića, Knjižnice grada Zagreba o korištenju resursa narodne knjižnice u izvanrednoj situaciji pandemije virusa SARS-CoV-2 i bolesti COVID-19 koju taj virus uzrokuje.

Pristup/metodologija/dizajn. Za potrebe istraživanja u radu korištena je metoda ankete uz primjenu tiskanog anketnog upitnika u prostoru Knjižnice i čitaonice Bogdana Ogrizovića, Knjižnice grada Zagreba uz primjenu prigodnog uzorka ispitanika.

Rezultati. Rezultati istraživanja pokazali su kontinuirano zanimanje korisnika Knjižnice i čitaonice Bogdana Ogrizovića, Knjižnice grada Zagreba prema navedenoj knjižnici, unatoč izvanrednoj situaciji. Rezultati su također pokazali povećano korištenje digitalnih izvora informacija tijekom razdoblja u kojem je knjižnica bila zatvorena zbog pandemije. Rezultati su pokazali i koje su usluge knjižnice bile najtraženije tijekom razdoblja u kojem je ona bila zatvorena zbog pandemije. Nadalje, rezultati ukazuju

Vjesnik bibliotekara Hrvatske 64, 1(2021), 27-52

ISSN 0507-1925 
na pretežitu orijentaciju korisnika prema tiskanoj građi i želju za povećanom nabavom te vrste građe, ali da se usporedno nabavlja i digitalna građa.

Praktična primjena. Rezultati istraživanja korisnika Knjižnice i čitaonice Bogdana Ogrizovića, Knjižnice grada Zagreba primjenjivi su u planiranju nabave građe, kao i u planiranju godišnjih programa knjižnice, uključujući i dugoročne planove razvoja digitalnih izvora informacija u narodnim knjižnicama.

Društveni značaj. Rad izravno ukazuje na stabilan položaj narodne knjižnice u lokalnoj zajednici $i$ potrebu korisnika za uslugama narodnih knjižnica u izvanrednoj $i$ kriznoj situaciji izazvanoj pandemijom koronavirusa i potresom, čime narodne knjižnice nastavljaju biti stup društva kada su u pitanju informacijske i srodne usluge lokalnoj zajednici.

Originalnost/vrijednost. Originalnost rada ogleda se u činjenici da je istraživanje korisnika Knjižnice i čitaonice Bogdana Ogrizovića, Knjižnice grada Zagreba provedeno u izvanrednoj i kriznoj situaciji, a riječ je o temi kojom se narodne knjižnice rjeđe bave dok takav događaj traje.

Ključne riječi: Hrvatska, istraživanje korisnika, krizna situacija, narodna knjižnica, SARS-CoV-2

\begin{abstract}
Purpose. The aim of the paper is to present the results of the research of users of the Library and Reading Room Bogdan Ogrizović, Zagreb City Libraries about the use of library resources in the crisis caused by the SARS-CoV-2 virus and the COVID-19 illness it causes.
\end{abstract}

Approach/methodology/design. A printed questionnaire was used as a principal method for research in the premises of the Library and Reading Room Bogdan Ogrizović, Zagreb City Libraries on a convenience sample of research participants.

Findings. The results of the research have shown a continuing interest of the library users for the Library and Reading Room Bogdan Ogrizović, Zagreb City Libraries in spite of an emergency situation caused by Covid. The results have also shown an increased use of digital information resources in the period of time when the library was closed due to the pandemic. The results showed which library services were used the most when the library was closed also due to the pandemic. Furthermore, the results indicated a dominant orientation of the library users towards printed library material as well as the desire for the increased acquisition of this type of library material, together with the digital versions in the future.

Practical implications. The results of the research of library users in the Library and Reading Room Bogdan Ogrizović, Zagreb City Libraries are applicable in the planning process of library material acquisition as well as for the development of annual pro- 
grams in libraries and long-term plans of development of digital information resources in public libraries.

Social implications. The paper indicates a stable position of public libraries in local communities and the constant need of users for public libraries in an emergency situation caused by the pandemic and an earthquake. Therefore, public libraries continue being a pillar of society in emergency situations and crises offering their information and related library services to the local community.

Originality/value. The research of the library users of the Library and Reading Room Bogdan Ogrizović, Zagreb City Libraries was conducted during ongoing emergency situation and crisis which is a topic less researched in public libraries. The research in this article is a rare example of an investigation of public library users in a real emergency situation.

Keywords: Croatia, crisis, public library, SARS-CoV-2, user studies

\section{Uvod}

Kao i prije tijekom povijesti, knjižnice se ponovno nalaze u zahtjevnoj situaciji. Pandemija virusa SARS-CoV-2 (u nastavku rada - koronavirusa) koji izaziva bolest COVID-19 prisila je mnoge države na zatvaranje vrata brojnih ustanova $u$ području kulture, među kojima se nalaze i knjižnice. ${ }^{1}$ Tim činom korisnici knjižnica ostali su bez mogućnosti pristupa knjižničnim fondovima, uslugama koje knjižnice nude, ali prije svega, prostorima knjižnica u kojima su se odvijale brojne aktivnosti atraktivne korisnicima. Pojedine su knjižnice u kriznom razdoblju, u kojem su privremeno bile zatvorene, svojim korisnicima pojačano nudile usluge i građu u digitalnom obliku dostupne putem interneta. U tim teškim trenucima za knjižnice, knjižničare i njihove korisnike, knjižnice su i dalje nastavile ispunjavati svoju osnovnu funkciju zadovoljavanja informacijskih potreba i pružanja informacijskih usluga pristupa informacijskim izvorima. ${ }^{2}$ Ovaj rad predstavit će rezultate istraživanja korisnika Knjižnice i čitaonice Bogdana Ogrizovića, Knjižnice grada Zagreba o korištenju usluga knjižnice u izvanrednoj situaciji izazvanoj pandemijom koronavirusa i potresom u Zagrebu 22. 3. 2020. Knjižnicu i čitaonicu Bogdana Ogrizovića o kojoj je u ovom radu riječ, osnovala je Družba „Braća Hrvatskog Zmaja“" 1907. po nazivom Gradska knjižnica, a Općina Centar 1947. promijenila je ime knjižnice i čitaonice nazvavši je prema poznatom profesoru fizike i matematike, hrvatskom antifašistu Bogdanu Ogrizoviću (1911. - 1943.).

1 Library closures around the world. [citirano: 2021-01-24]. Dostupno na: https://www.ifla.org/ covid-19-and-libraries\#closures.

2 Altay, A.; A. Tekin; B. Dursun; M. Yayla. The role of the libraries in the information society. 2012. [citirano: 2020-05-01]. Dostupno na: http://hdl.handle.net/20.500.11857/131. 
Od 1961. godine knjižnica se nalazi na adresi Preradovićeva 5 (iz studentske menze u odgovarajući knjižni prostor preuredio ju je arhitekt Vjenceslav Richter) ${ }^{3}$ i u 2019. godini imala je 16453 upisana člana te brojne kulturne događaje koji je čine jednom od najpopularnijih zagrebačkih narodnih knjižnica. ${ }^{4}$

\section{Pogledi na položaj knjižnica u društvu i njihove odnose prema korisnicima u vrijeme pandemije koronavirusa}

Razvoj je knjižnica općenito u posljednjih nekoliko desetljeća obilježen mnogim i raznovrsnim političkim, ekonomskim i tehnološkim promjenama u društvu. U brojnim znanstvenim, stručnim i popularnim radovima potvrđeno je kako su knjižnice neodvojiv dio društva kojemu nude niz usluga koje nitko drugi ne nudi, a koje društvo prepoznaje i na odgovarajući način periodično vrednuje omogućujući knjižnicama financiranje i nastavak rada. ${ }^{5}$ Sve su knjižnice bez obzira na vrstu važne za razvoj društva, a posebnu ulogu u društvu imaju narodne knjižnice jer su namijenjene svim grupama stanovnika. Prema Scottu, ${ }^{6}$ narodne knjižnice imaju izravan utjecaj na izgradnju društva jer su demokratski izjednačitelji, otvorene su svima, pružaju pristup informacijama koje ljudima pomažu u unaprjeđenju njihovih života, života njihovih obitelji i života zajednice. Nadalje, isti autor naglašava

370 godina Knjižnice i čitaonice Bogdana Ogrizovića. [citirano: 2021-02-24]. Dostupno na: http://fama.com.hr/70-godina-knjiznice-i-citaonice-bogdana-ogrizovica/.

4 Izvještaj o radu Knjižnica grada Zagreba za 2019. godinu. Zagreb: Knjižnice grada Zagreba, 2020. [citirano: 2021-02-24]. Dostupno na: https://issuu.com/knjinicegradazagreba/docs/izvje_ taj_za_uv_2019. Str. 8.

5 White, B. Guaranteeing access to knowledge: the role of libraries. // WIPO Magazine, 4 (2012). [citirano: 2020-05-01]. Dostupno na: https://www.wipo.int/wipo_magazine/ en/2012/04/article 0004.html., Webb, S. M. The role of public libraries in society: a case study from a poor suburb of Windhoek, Namibia, 2010. [citirano: 2020-05-01]. Dostupno na: http://hdl.handle.net/2142/14996., Role of libraries and information centres in modern society. // Development of libraries and their role in society. 2017. [citirano: 2020-05-01]. Dostupno na: http://egyankosh.ac.in/handle/123456789/33044., Aabø, S. Are public libraries worth their price? A contingent valuation study of Norwegian public libraries. // New Library World 106, 1218/1219(2005), 487-495., Aabø, S. The role and value of public libraries in the age of digital technologies. // Journal of Librarianship and Information Science 37, 4(2005), 205-211., Mainka, A.; S. Hartmann; L. Orszullok; I. Peters; A. Stallmann; W. G. Stock. Public libraries in the knowledge society: core services of libraries in informational world cities. // Libri 6, 4(2013), 295-319., Kerslake, E.; M. Kinnell. Public libraries, public interest and the information society: theoretical issues in the social impact of public libraries // Journal of Librarianship and Information Science 30, 3(1998), 159-167., Rooney-Browne, C.; D. McMenemy. Public libraries as impartial spaces in a consumer society: possible, plausible, desirable? // New Library World 111, 11/12(2010), 455-467., Baker, D.; W. Evans. Libraries and society: role, responsibility and future in an age of change. Oxford: Chandos Publishing, 2011.

6 Scott, R. The role of public libraries in community building. // Public Library Quarterly 30, 3(2011), str. 191. 
kako knjižnice danas funkcioniraju poput robusnih komunikacijskih središta, koja često pružaju usluge koje ljudi ne mogu drugdje dobiti, ${ }^{7}$ pa su stoga vrlo popularna sastajališta korisnika.

O promjenama u društvu i knjižnicama često se piše s različitih stajališta. Ta su stajališta važna kako bi bilo moguće razumjeti što knjižnice znače pojedinoj lokalnoj zajednici i društvu u cjelini, osobito u kriznim situacijama.

Promišljajući o promjenama u društvu i njihovu utjecaju na knjižnice, Audunson $^{8}$ smatra kako današnje globalizirano društvo ocrtavaju dva bitna pravca razvoja: jedan su pravac kulturne i društvene promjene koje uzrokuju migracije i rast multikulturnog društva, a drugi je pravac povezan s digitalizacijom i rastom takozvanog informacijskog društva ili društva znanja. I kulturne i društvene promjene, kao i digitalizacija nedvojbeno utječu na knjižnice i ponudu programa i usluga koje nude u svoje prostoru. ${ }^{9}$

U slučaju narodnih knjižnica rezultati promjena u digitaliziranom i modernom društvu (jer nisu sva društva digitalizirana) jesu nove uloge knjižnica u javnoj sferi (tj. areni u kojoj se javna sfera nalazi između privatne sfere, tržišta i države) u kojoj se raspravlja o javnim pitanjima. Javnost, a time i knjižnice, dio su društvenog života koji je u načelu otvoren svima, a čine ga neovisni pojedinci. ${ }^{10}$ Widdersheim i Koizumi ${ }^{11}$ predložili su stoga model od šest dimenzija koji definira javnu sferu u narodnim knjižnicama i jednu od predloženih dimenzija opisali su uz pomoć četiriju poddimenzija: građanski diskurs, integracija građana, interakcija sa zbirkama i interakcija s osobljem. Tako su stvorili vlastiti okvir koji se u praksi, u knjižnicama čije su dokumente proučavali, pokazao ostvarivim i stvarnim, čime su knjižnice povezali s neposrednom okolinom u kojoj one djeluju.

\footnotetext{
7 Isto.

8 Audunson, R. The public library as a meeting-place in a multicultural and digital context: the necessity of low-intensive meeting-places. // Journal of Documentation, 61, 3(2005), str. 429.

9 Wenborn, C. How technology is changing the future of libraries. // The Wiley Network. 2018. [citirano: 2020-05-01]. Dostupno na: https://www.wiley.com/network/librarians/ library-impact/how-technology-is-changing-the-future-of-libraries., Johnston, C. Electronic technology and its impact on libraries, // Journal of Librarianship and Information Science 30, 1(1998), 7-24. Dostupno i na: http://citeseerx.ist.psu.edu/viewdoc/download?doi=10.1.1.870.3629\&rep=rep1\&type=pdf. [citirano: 2020-05-01], Tait, E.; K. Martzoukou; P. Reid. Libraries for the future: the role of IT utilities in the transformation of academic libraries. // Palgrave Communication 2, 16070(2016). DOI: https://doi.org/10.1057/palcomms.2016.70., Uddin, J.; N. Hasan. Use of information technology in library service: a study on some selected libraries in northern part of Bangladesh. // International Journal of Library and Information Science 4, 3(2012), 34-44.

10 Widdersheim, M. M.; M. Koizumi. Conceptual modelling of the public sphere in public libraries. // Journal of Documentation 72, 3(2016), 591-610.

11 Isto.
} 
Osim društva u cjelini, knjižnice su posebno posvećene jednom njegovom užem dijelu: lokalnim zajednicama u kojima djeluju. Pareek i Gangrade ${ }^{12}$ ponudili su modele za razumijevanje uloga knjižnice u modernoj zajednici:

- tradicionalna knjižnica kao institucija sjećanja

- knjižnica kao središte učenja i istraživanja

- knjižnica kao središte kulture i komunikacije

- elektronička knjižnica

- digitalna knjižnica

- virtualna knjižnica kao knjižnica bez zidova.

Uz navedene modele koji uključuju razne pojavne i tehnološki poduprte varijante modernih knjižnica, za narodnu knjižnicu 21. stoljeća može se reći kako inspirira, podržava učenje, promiče znanje i pismenost, učvršćuje zajednice i pruža slobodan pristup informacijama, tehnologiji i vještinama. ${ }^{13}$ Zajednice i knjižnice moraju nadograđivati ono što knjižnice rade najbolje u zajednici i podržati budući razvoj knjižnice, kao platforme za učenje i inovacije u zajednici kao civilnom kreativnom prostoru za okupljanja, i kao prvaka intelektualne slobode i važnih javnih politika koje podupiru tu slobodu. ${ }^{14}$ One služe „kao sidro zajednice koje zadovoljava potrebe pojedinaca u lokalnoj zajednici bez obzira na dob i dionicu života“. ${ }^{15}$ Njihova je uloga kao ustanova podupirati demokraciju i racionalni javni diskurs i izgradnju zajednica. ${ }^{16}$ Narodne knjižnice nisu samo mjesta u kojima je moguće posuditi ili čitati knjige ili čak pristupiti digitalnoj građi, one su i ključni resurs zajednice i ustanove koje mogu poslužiti kao mjesta odvijanja događaja u zajednici i imaju ulogu pristupne točke za povezivanje pojedinaca, povezivanje ljudi s lokalnim zajednicama i povezivanje zajednica sa širim društvom. ${ }^{17}$ Biando, Rauseo i Unge ponudile su svoje viđenje važnosti knjižnice u zajednici i oblikovale čak 23 razloga zašto knjižnice imaju važno mjestu u gradu:

- knjižnice pomažu revitalizirati manje privilegirane četvrti

- knjižnice su važan partner u održivosti (grada)

\footnotetext{
12 Pareek, N.; A. Gangrade. Role of the libraries as information resources in globalization. // International Journal of Librarianship and Administration 7, 1(2016), 13-23.

13 Garmer, A.K. Public libraries in the community. // I/S A Journal of Law and Policy for the Information Society, 2016. Str. 2 [citirano: 2020-05-01]. Dostupno na: https://kb.osu.edu/bitstream/ handle/1811/81147/ISJLP_V13N1_001.pdf.

14 Isto, str. 22-26.

15 Taylor, M.; M. E. Pratt; R. A. Fabes. Public libraries as a context for the study of learning and development. // Journal of Higher Education Outreach and Engagement 23, 2(2019), str. 51.

16 Audunson, R.; S. Aabø; R. Blomgren; H. C. Hobohm; H. Jochumsen; M. Khosrowjerdi; R. Mumenthaler i suradnici. Public libraries as public sphere institutions: a comparative study of perceptions of the public library's role in six European countries. // Journal of Documentation 75, 6(2019), str. 1397.

17 Goulding, A. Engaging with community engagement: public libraries and citizen involvement. // New Library World 110, 1-2(2009), str. 47-48.
} 
- knjižnične zbirke nastaju na temelju potreba zajednice

- arhivi čuvaju povijesne artefakte, usmenu povijest, projekte digitalne povijesti relevantne zajednici uključujući i grupe manjina;

- knjižnice su mjesta u koja ljudi dolaze upoznati sebe i svoje zajednice

- knjižnice služe kao katalizatori rješavanja društvenih problema

- knjižnice koje slave, promoviraju i promišljaju važne demokratske vrijednosti dio su političkog života zajednice

- zgrade knjižnica kao arhitektonske strukture kulturno su relevantne

- knjižnice pružaju važne poslovne informacije, posebno za male tvrtke

- knjižnice pomažu osigurati neengleskim govornicima zastupljenost u zajednici

- knjižnice imigrantima pružaju važne informacije o prilikama da se povežu sa svojim novim zajednicama

- knjižnice pružaju informacije i druge resurse LGBTIQ korisnicima

- knjižnice pružaju informacije i druge resurse korisnicima s posebnim potrebama

- knjižnice omogućavaju pristup pogledima na svijet koji nisu dio glavne struje i daju mogućnost predstavljanja lokalnim umjetnicima

- knjižnice pružaju mogućnost besplatne nastave kojom ohrabruju priznanje umjetnicima (i umjetnosti) i sudjelovanje u umjetnosti

- knjižnice svima omogućavaju pristup umjetnosti, a ne samo onima koji je mogu priuštiti

- knjižnice služe kao pučka sveučilišta

- knjižnice pružaju prilike za udaljeni pristup, omogućavajući onima koji ne mogu doći u knjižnicu pristup kulturnoj i obrazovnoj ponudi knjižnice

- osim što nude sadržaj, knjižnice omogućavaju korisnicima stvaranje vlastitog sadržaja

- knjižnice promoviraju građanski diskurs

- knjižnice poučavaju tinejdžere važnim vještinama

- knjižnice nude pomoć pri izradi zadaća, ljetnom čitanju knjiga za djecu i tinejdžere i pomažu u premošćivanju ekonomskih razlika koje utječu na akademski uspjeh studenata

- knjižnice su važni partneri u razvoju djeteta. ${ }^{18}$

18 Biando E. J.; M. S. Rauseo; K. R. Unge. Community centered: 23 reasons why your library is the most important place in town. // Public Libraries Online. 2013. [citirano: 2020-05-01]. Dostupno na: http://publiclibrariesonline.org/2013/04/community-centered-23-reasons-why-your-library-is-the-most-important-place-in-town/. 
Audunson ${ }^{19}$ je u svom radu na temu knjižnica u multikulturalnom i digitalnom kontekstu promišljao i o ulozi prostora knjižnice i zaključio kako je riječ o mjestima niskog intenziteta jer one nude prostor za sastajanje u neformalnom krugu odvojenom od službenih mjesta za srodne aktivnosti. Upravo je prostor knjižica doživio veliku promjenu od kraja devetnaestog stoljeća do kraja dvadesetog stoljeća transformacijom iz spremišta knjiga u društveni prostor i od tada se u znanstvenoj i stručnoj literaturi iznova propituje uloga knjižnice u društvu i doprinos knjižnice razvoju društva. Narodne knjižnice tipičan su ali i najbolji primjer društvenog prostora. One su istodobno univerzalni otvoreni prostor za sastanke bilo da je riječ o neformalnim sastancima među samim korisnicima knjižnice ili onima formalnije prirode povezanima s programima knjižnice koji uključuju kontakt s osobljem knjižnice i izvođačima programa. ${ }^{20}$

Na prostor knjižnice utjecaj je imala i digitalizacija koja je također sudjelovala u preobrazbi prostora knjižnice jer svjedočimo transformaciji više ili manje pasivnih zbirki knjiga i drugih medija u aktivni prostor za pružanje iskustva i inspiracije te kao lokalne točke sastajanja. ${ }^{21}$ Jochumsen i Hvenegaard ${ }^{22}$ također su promišljali novo značenje prostora narodne knjižnice kroz svojevrsnu viziju knjižnice kao presjek četiriju prostora:

- prostora inspiracije

- prostora učenja

- prostora sastajanja i

- prostora izvedbe.

Navedena četiri prostora nisu fizičke „prostorije“, već mogućnosti koje mogu biti ostvarene u fizičkom prostoru knjižnice ali i na internetu. Cilj je omogućiti tim četirima prostorima interakciju tako da ih se inkorporira u knjižničnu arhitekturu, dizajn, usluge, programe i izbor partnerstava. ${ }^{23}$ Prostor inspiracije predstavlja prostor za smislena iskustva, tj. iskustva koja preobražavaju našu percepciju uz pomoć pričanja priča ili nekim umjetničkim izražajem u više medija i žanrova. Prostor učenja prostor je u kojem djeca, mladi i odrasli mogu otkriti i istražiti svijet i time povećati svoje kompetencije i mogućnosti uz pomoć slobodnog i neograničenog pristupa informacijama i znanju. Prostor sastajanja otvoreni je javni prostor i prostor između posla i doma u kojem građani susreću druge ljude nalik sebi, ali i one različite. Bit je u slučajnom susretu u manjem prostoru u inače

\footnotetext{
19 Audunson, R. Nav. dj., str. 434.

20 Vårheim, A.; S. Steinmo; E. Ide. Do libraries matter? Public libraries and the creation of social capital. // Journal of Documentation 64, 6(2008), 886-888.

${ }^{21}$ Jochumsen, H.; C.H. Rasmussen; D. Skot-Hansen. The four spaces - a new model for the public library. // New Library World 113, 11-12(2012), str. 588.

22 Isto, str. 586-597.

23 Isto, str. 590.
} 
segmentiranom društvu u kojem se susreću ljudi različitih interesa i vrijednosti. Prostor izvedbe prostor je u kojem su korisnici u interakciji jedni s drugima kako bi stvorili nove umjetničke izražaje. Ujedno može poslužiti kao platforma za posredovanje objavljivanjem i distribucijom radova i proizvoda korisnika i za pružanje pozornice njihovim aktivnostima. ${ }^{24}$

Pozornica za aktivnosti koje nudi knjižnica podrazumijeva već spomenutu otvorenost. Otvorenost knjižnica, a osobito narodnih knjižnica, čini ih idealnim mjestima gdje se ljudi mogu sastajati, doći do informacija i građe za čitanje koja im je potrebna i u kojima susreću druge ljude i ideje. ${ }^{25}$ Knjižnice su jedno od rijetkih mjesta gdje može otići svatko, znajući kako će biti dobrodošao, gdje nitko nikog neće pokušati promijeniti, gdje nitko neće ništa pokušati prodati i gdje će se nuditi prijateljske usluge. ${ }^{26}$

S obzirom na sadašnje uvjete epidemije koronavirusa u Republici Hrvatskoj, otvorenost knjižnica uvjetovana je administrativnim i epidemiološkim mjerama države, pa se zbog strogih uvjeta boravka u zatvorenim prostorima knjižnice moraju prilagoditi novim okolnostima, koje za njih znače manji broj korisnika koji istodobno mogu boraviti u istom prostoru, nemogućnost korištenja čitaonica, nemogućnost organiziranja većih događaja, karantenu i dezinfekciju vraćene građe, ${ }^{27}$ promijenjeni raspored rada knjižničara itd. ${ }^{28}$ Stoga su u jednom trenutku, zbog objektivnih razloga, prostori knjižnica bili zatvoreni za fizički dolazak korisnika ili je broj korisnika morao biti znatno smanjen. Slična situacija dogodila se u brojnim državama širom svijeta, o čemu je IFLA redovito i iscrpno izvještavala. ${ }^{29}$

Knjižnice se zbog toga, ali i zbog drugih naglih promjena u društvu izazvanih pandemijom koronavirusa, nastoje prilagoditi novonastalim uvjetima, pa dosadašnjim i postojećim uslugama dodaju rastući broj internetskih izvora kojima korisnici mogu pristupiti iz udobnosti svojih domova ili s drugih lokacija. ${ }^{30}$ Narodne knjižnice time dokazuju da se prilagođavaju i evoluiraju u skladu s potrebama svojih zajednica. ${ }^{31}$ Upravo je informacijska i komunikacijska tehnologija jedan

\footnotetext{
24 Isto, str. 590-593.

25 Johnson, C. A. Do public libraries contribute to social capital? A preliminary investigation into the relationship. // Library \& Information Science Research 32(2010), str. 147.

26 The intrinsic value of libraries as public spaces: technology and digital services reflect the changing role of libraries. Civica Group Limited, 2016. Str. 7. [citirano: 2020-05-01]. Dostupno na: https://www.uts.edu.au/sites/default/files/Civica+Intrinsic+value+of+libraries+report.pdf.

27 Tri dana izolacije: evo kako knjige koje ste vratili u knjižnicu provode vrijeme u karanteni. [citirano: 2020-10-01]. Dostupno na: https://www.sibenik.in/sibenik/tri-dana-izolacije-evo-kako-knjige-koje-ste-vratili-u-knjiznicu-provode-vrijeme-u-karanteni/122088.

28 HZJZ objavio upute za korištenje knjižnica i antikvarijata. [citirano: 2020-10-01]. Dostupno na: https://ezadar.net.hr/kultura/3805627/hzjz-objavio-upute-za-koristenje-knjiznica-i-antikvarijata/.

29 Library closures. Nav. dj.

30 Jochumsen, H.; C.H. Rasmussen; D. Skot-Hansen. Nav. dj., str. 587.

31 Taylor, M.; M. E. Pratt; R. A. Fabes. Nav. dj., str. 52.
} 
od najsnažnijih čimbenika promjena u knjižnicama, koja im je pomogla u unaprjeđenju poslovanja, razvoju i korištenju novih knjižničnih usluga i povezivanju korisnika s knjižnicom. Stav prema informacijskoj i komunikacijskoj tehnologiji nije uvijek bio povoljan te je u nekim promišljanjima o budućnosti knjižnica bilo označen kao čimbenik koji će značiti kraj knjižnica, a to se ipak nije dogodilo. ${ }^{32}$

Pristup fizičkom prostoru knjižnica, kao i pristup uslugama i zbirkama putem interneta čine još jednu dimenziju otvorenosti knjižnica svojim korisnicima te su zbog toga među popularnijim institucijama u društvu (bilo da je riječ o prostoru knjižnice, bibliobusu ili web-stranici knjižnice). ${ }^{33} \mathrm{U}$ novonastalim pandemijskim okolnostima, a posebno u situaciji zatvaranja knjižnica u proljeće 2020. godine, korisnici su se preko noći okrenuli digitalnim izvorima građe i informacija koje su narodne knjižnice imale u svojoj ponudi. U modernom društvu, narodne knjižnice tako uspješno provode fleksibilniju komunikaciju, fleksibilniju organizaciju rada, dok je razvoj usluga utemeljen na kvaliteti i orijentaciji prema korisniku, ${ }^{34}$ osobito komuniciranjem putem interneta. Bez obzira na vrstu, knjižnice su mjesta gdje se ljudi sastaju zbog mogućnosti neometanog komuniciranja na raznovrsne načine. ${ }^{35}$ Narodne knjižnice u ovoj godini čeka vrednovanje korištenja upravo tog njihovog segmenta rada, a koji je godinama polako bio uvođen u svakodnevnu radnu praksu.

Promatrajući situaciju povezanu s pandemijom koronavirusa izvan Hrvatske, moguće je utvrditi kako su knjižnice širom svijeta odgovorile na izazov najnovije pandemijske krize. Corsillo tako navodi poznate činjenice kako narodne knjižnice imaju važnu ulogu u obrazovanju svojih korisnika, u njihovom povezivanju, zabavljanju i sve to čine pronalazeći načine kako usluge ponuditi u uvjetima kada su zatvorene za korisnike. Nabrajajući primjere takvih usluga, spominje New York Public Library koja je pružala udaljeni pristup bazama podataka kojima je u normalnim uvjetima pristup ograničen na prostor knjižnice te je ublažila uvjete za pristup digitalnim sadržajima u vrijeme pandemije koronavirusa. Autorica navodi i primjer vlastite knjižnice koja je povećala financijska sredstva za razvoj digitalnih zbirki kako bi većem broju korisnika bilo omogućeno njihovo korištenje te su ponudili aplikaciju za razgovor kako bi savjetovali korisnike i pomagali im

\footnotetext{
32 Freeman, G.T. The library as place: changes in learning patterns, collections, technology, and use. // Library as Place: Rethinking Roles, Rethinking Space. Council on Library and Information Resources. Washington, D.C.: Council on Library and Information Resources, 2005. Str. 2. [citirano: 2020-05-01]. Dostupno na: https:/www.clir.org/wp-content/uploads/sites/6/pub129.pdf.

33 Geiger, A.W. Millennials are the most likely generation of Americans to use public libraries. // Pew Research Center. 2017. [citirano: 2020-05-01]. Dostupno na: https://www.pewresearch.org/ fact-tank/2017/06/21/millennials-are-the-most-likely-generation-of-americans-to-use-public-libraries/.

34 Pareek, N.; A. Gangrade. Nav. dj. Str. 16-17.

35 Freeman, G.T. Nav. dj., str. 5-6.
} 
u vezi s digitalnim izvorima informacija i informacijskim upitima. ${ }^{36}$ Amajlmi i Albudaiwi istraživali su upotrebu društvenih mreža u New York Public Library u vrijeme pandemije bolesti COVID-19. Zaključili su da je ta knjižnica nastavila raditi ono što je radila i ranije. Dok su prostori knjižnice bili zatvoreni za korisnike, usluge su preseljene na internet kako bi se korisnicima pružile tražene informacije. Informacije se nisu odnosile samo na informacijske izvore u ponudi knjižnice, što je ujedno i kritika pojedinim knjižnicama koje su komunicirale s korisnicima u vrijeme pandemije koronavirusa, nego su svojim korisnicima na društvenim mrežama nudili informacije o drugim informacijskim izvorima koji su korisnicima pomogli tijekom pandemije. Tako su knjižnice proširile svoju uobičajenu ulogu. ${ }^{37} \mathrm{U}$ Italiji su knjižnice također koristile razne alate za komunikaciju s korisnicima, od običnog telefona do video konferencija i društvenih medija kako bi se uspostavila bolja komunikacija s korisnicima. ${ }^{38} \mathrm{U}$ publikaciji pod naslovom Libraries in the pandemic: evolving services to meet local need navedene su važne aktivnosti koje su britanske knjižnice provodile i provode u vrijeme pandemije koronavirusa: povećanje količine digitalnih izvora informacija, povezivanje s korisnicima telefonom, ponuda volonterske pomoći knjižničnog osoblja izvan knjižnice; inoviranje i kreativnost kao pomoć lokalnoj zajednici (izrada vizira uz pomoć 3D printera). Također, navedena je podrška pismenosti i učenju, pružanje usluga digitalno isključenima posudbom tableta; donošenje građe na kućni prag korisnicima koji nisu mogli doći u knjižnicu itd..$^{39}$ To su samo neki primjeri koji su uspješno zabilježeni u recentnoj literaturi iz 2020. godine, pa se očekuje povećani broj radova o sličnim temama u 2021., nakon što knjižnice dodatno istraže uvjete svoga rada u pandemijskoj krizi koja se nastavila i na početku 2021.

\section{Istraživanje korisnika Knjižnice i čitaonice Bogdana Ogrizovića u Zagrebu o njihovu odnosu prema knjižnici u kriznoj situaciji iza- zvanoj epidemijom virusa SARS-CoV-2 (koronavirusa)}

Knjižnice u svijetu redovito provode istraživanja svojih korisnika u svrhu poboljšanja svojih usluga. One to čine i u izvanrednim okolnostima poput aktualne epidemije koronavirusa u Hrvatskoj. Ovo je istraživanje pokrenuto sa svrhom utvrđivanja snage odnosa korisnika i narodne knjižnice u izvanrednoj situaciji po-

\footnotetext{
36 Kaser Corsillo, G. COVID-19: The impact on public libraries. // Public Libraries Online. 2020. DOI: https://doi.org/10.1080/01616846.2020.1827618.

37 Alajmi, B. M.; D. Albudaiwi. Response to COVID-19 pandemic: Where do public libraries stand? // Public Library Quarterly. 2020. DOI: https://doi.org/10.1080/01616846.2020.1827618.

38 Tammaro, A. M. COVID 19 and libraries in Italy. // International Information \& Library Review 52,3(2020), str. 216. DOI: https://doi.org/10.1080/10572317.2020.1785172.

39 Libraries in the pandemic: evolving services to meet local need. // Libraries Connected. [citirano: 2021-01-24]. Dostupno na: https://www.librariesconnected.org.uk/resource/libraries-pandemic-evolving-services-meet-local-need.
} 
put pandemije koronavirusa. Cilj istraživanja bio je prikupiti podatke o korištenju građe i usluga navedene Knjižnice i čitaonice u razdoblju prije zatvaranja svih knjižnica sustava Knjižnice Grada Zagreba, koje se dogodilo 19. 3. 2020.:

„Knjižnice grada Zagreba od danas (19. ožujka 2020.) u idućih 30 dana zatvorene su za posjet članova i korisnika zbog protuepidemijskih mjera u širenju bolesti COVID-19, a prema odluci Stožera za civilnu zaštitu RH o mjerama ograničavanja društvenih okupljanja, rada u trgovini, uslužnih djelatnosti i održavanja sportskih i kulturnih događanja“" ${ }^{40}$

Tijekom nešto više od mjesec dana, kada su knjižnice tog sustava bile zatvorene uz moguću posudbu i korištenje $e$-građe i netom nakon njihova ponovnog otvaranja za posudbu i povrat posuđene (tiskane) građe 27. 4. 2020.: „Od 27. travnja 2020. Knjižnice grada Zagreba otvorene su za korisnike u ograničenom opsegu, samo za povrat i posudbu građe, bez korištenja čitaonica i rade prema ljetnom radnom vremenu“ “ ${ }^{41}$ Riječ je doista o iznimnoj situaciji koju je dodatno pogoršao razorni potres koji je pogodio Zagreb 22. 3. 2020., a koji srećom nije nanio veću štetu Knjižnici i čitaonici Bogdana Ogrizovića u Zagrebu u kojoj je provedeno istraživanje korisnika za potrebe ovog rada. Glavna hipoteza istraživanja jest da korisnici knjižnice nastavljaju koristiti usluge i građu knjižnice i u kriznoj situaciji u svim dostupnim oblicima i time iskazuju stabilnost odnosa s knjižnicom.

\subsection{Metoda istraživanja}

Istraživanje je provedeno među svim korisnicima koji su stupili u prostor Knjižnice i čitaonice Bogdana Ogrizovića, Knjižnice grada Zagreba. Za instrument istraživanja odabrana je anketa te je ispitanicima ponuđen tiskani anketni upitnik koji se sastojao od 10 pitanja zatvorenog tipa. Istraživanje je provedeno od 2. 6. 2020. do 4. 9. 2020. u prostoru Knjižnice i čitaonice Bogdana Ogrizovića, Knjižnice grada Zagreba. U istraživanju je sudjelovalo ukupno 69 ispitanika. Premda se taj broj može činiti malim, potrebno je još jednom naglasiti kako se zbog važećih epidemioloških mjera korisnici Knjižnice i čitaonice Bogdana Ogrizovića nisu htjeli zadržavati u prostoru knjižnice duže no što je to potrebno za povrat i posudbu građe. Nadalje, razorni potres dodatno je otežao pristup užem središtu Zagreba u kojem se nalazi knjižnica jer je taj dio grada zbog opasnosti od padanja dijelova fasada zgrada ostao i bez javnog prijevoza, što je dodatno utjecalo na broj korisnika koji su dolazili u knjižnicu. Zbog navedenog, korisnici Knjiž-

${ }^{40}$ Knjižnice grada Zagreba. Događanja. [citirano: 2020-06-01]. Dostupno na: http://www.kgz.hr/ $\mathrm{hr} /$ dogadjanja/10?page=7\&datumod=01.03.2020\&datumdo=30.04.2020).

${ }^{41}$ Knjižnice grada Zagreba. Novo radno vrijeme Knjižnica grada Zagreba od 27. travnja 2020. [citirano: 2020-05-01]. Dostupno na: http://www.kgz.hr/hr/dogadjanja/natjecanje-u-citanju-naglas-54461/novosti/novo-radno-vrijeme-knjiznica-grada-zagreba-od-27-travnja-2020/53332. 
nice i čitaonice Bogdana Ogrizovića, Knjižnice grada Zagreba nisu se u prostoru knjižnice zadržavali duže od trajanja evidentiranja povrata i posudbe građe te je zbog toga tek manji broj korisnika sudjelovao u ovom istraživanju.

\subsection{Rezultati istraživanja}

U ovom dijelu rada bit će predstavljeni rezultati istraživanja u Knjižnici i čitaonici Bogdana Ogrizovića, Knjižnice grada Zagreba (u nastavku teksta rada knjižnici). Ispitanicima je ponuđeno 10 pitanja zatvorenog tipa, na koja su mogli dati jedan ili više odgovora, ovisno o pitanju. Zatvoreni tip odgovora odabran je kako bi ispitanici mogli dati odgovore na pitanja u što kraćem roku, jer su se zbog tada važećih epidemioloških mjera trebalo zadržavati što kraće u zatvorenom prostoru. Primjena takvih mjera utjecala je i na broj ispitanika koji su sudjelovali u istraživanju, što je već pojašnjeno.

U nastavku rada bit će prikazani rezultati svakog od ponuđenih 10 pitanja uz kratku interpretaciju rezultata.

1. Jeste li svratili u knjižnicu u prvom tjednu njezinog ponovnog otvaranja nakon 27. 4. 2020. (OZNAČITE JEDAN ODGOVOR)? $(\mathrm{N}=69)$

Na prvo pitanje odgovorilo je ukupno 69 ispitanika. 26 ispitanika ili $38 \%$ nije svratilo u knjižnicu u prvom tjednu njezina ponovnog otvaranja nakon 27. 4 . 2020., dok su 43 ispitanika ili $62 \%$ to učinili. Odluka o dolasku u knjižnicu ovisila je izravno o epidemiološkoj situaciji i propisanim mjerama zaštite zdravlja te sigurnosti korisnika u prostoru i široj okolici knjižnice nakon razornog potresa jer je uže središte grada Zagreba postalo vrlo problematično čak i za kraći boravak. Stoga je bilo za očekivati kako broj ispitanika neće biti velik, a među njima neće biti veći broj onih koji su odmah nakon otvaranja krenuli prema knjižnici, premda je u medijima bilo moguće vidjeti reportaže o redovima ispred pojedinih zagrebačkih knjižnica, uključujući i knjižnicu u kojoj je provedeno ovo istraživanje. ${ }^{42}$ Istraživanje je svakako bilo potrebno provesti kako bi se od korisnika knjižnice koji su pristali sudjelovati u istraživanju saznale činjenice, stavovi i mišljenja o korištenju usluga knjižnice u vrijeme epidemije i pandemije koronavirusa, tj. u izvanrednoj situaciji.

2. Je li se učestalost vaših dolazaka u knjižnicu promijenila zbog izbijanja epidemije koronavirusa (OZNAČITE JEDAN ODGOVOR)?

42 Pauček Šljivak, M. Krenulo je popuštanje mjera, Zagrepčani okupirali dućane: „Ljudi su željni svega“. // Indeks.hr. 2020. [citirano: 2020-05-01]. Dostupno na: https://www.index.hr/vijesti/ clanak/krenulo-je-popustanje-mjera-zagrepcani-okupirali-ducane-ljudi-su-zeljni-svega/2178444. aspx. 
Tablica 1. Učestalost dolazaka korisnika u knjižnicu uslijed izbijanja epidemije koronavirusa $(\mathrm{N}=68)$

\begin{tabular}{|l|l|l|l|l|}
\hline & $\begin{array}{l}\text { Da, dolazim rjeđe } \\
\text { nego prije izbijanja } \\
\text { epidemije koronavirusa }\end{array}$ & $\begin{array}{l}\text { Da, dolazim češće nego } \\
\text { prije izbijanja epidemije } \\
\text { koronavirusa }\end{array}$ & $\begin{array}{l}\text { Ne, dolazim } \\
\text { jednako često }\end{array}$ & $\begin{array}{l}\text { Ne mogu } \\
\text { procijeniti }\end{array}$ \\
\hline $\mathrm{N}$ & 26 & 2 & 35 & 5 \\
\hline$\%$ & 38 & 3 & 51 & 7 \\
\hline
\end{tabular}

Istraživanje za potrebe ovog rada provedeno je s vremenskim odmakom u odnosu na datum ponovnog otvaranja knjižnica u sustavu Knjižnica grada Zagreba, što je za ispitanike značilo mogućnost višekratnog dolaska u Knjižnicu i čitaonicu Bogdana Ogrizovića od trenutka njezina ponovnog otvaranja. Da je istraživanje provedeno neposredno nakon ponovnog otvaranja navedene knjižnice, ovo pitanje ne bi bilo potrebno. Na temelju dobivenih odgovora (ukupno 68 ispitanika, tablica 1), moguće je vidjeti kako je polovica ispitanika (51 \%) nastavila dolaziti u knjižnicu jednakom učestalošću, dok je tek nešto manji broj ispitanika (38 \%) smanjio učestalost svojih dolazaka u knjižnicu. Povećani broj dolazaka imao je neznatan broj ispitanika (3\%), a sličan je bio i broj ispitanika koji nisu mogli procijeniti učestalost svojih dolazaka u knjižnicu (7 \%). Sljedeće pitanje odnosilo se na namjeru dolaska u knjižnicu nakon njezina ponovnog otvaranja, koje je uslijedilo 27. 4. 2020.

3. Koliko često namjeravate dolaziti u knjižnicu nakon što je ponovno otvorena 27. 4. 2020. (OZNAČITE JEDAN ODGOVOR)?

Tablica 2. Namjera dolaska u knjižnicu nakon što je ponovno otvorena 27. 4. 2020. $(\mathrm{N}=68)$

\begin{tabular}{|l|l|l|l|l|l|l|}
\hline & $\begin{array}{l}\text { Više puta } \\
\text { tjedno }\end{array}$ & $\begin{array}{l}\text { Jednom } \\
\text { tjedno }\end{array}$ & $\begin{array}{l}\text { Jednom u } \\
\text { dva tjedna }\end{array}$ & $\begin{array}{l}\text { Jednom } \\
\text { mjesečno }\end{array}$ & $\begin{array}{l}\text { Jednom u } \\
\text { tri mjeseca }\end{array}$ & $\begin{array}{l}\text { Rjeđe od jednom } \\
\text { u tri mjeseca }\end{array}$ \\
\hline $\mathrm{N}$ & 21 & 10 & 15 & 20 & 2 & 0 \\
\hline$\%$ & 31 & 15 & 22 & 29 & 3 & 0 \\
\hline
\end{tabular}

Kao nadopuna prethodnog pitanja u ovom se pitanju od ispitanika (ukupno je odgovorilo 68 ispitanika) tražilo da konkretno odrede učestalost dolaska u knjižnicu nakon njezina ponovnog otvaranja 27. 4. 2020. Raspon odgovora (tablica 2) kretao se između više puta tjedno i jednom mjesečno (ukupno 97 \%), sugerirajući redovitost dolaženja ispitanika u knjižnicu. Pritom je potrebno naglasiti kako je najveći broj odgovora dan u kategoriji više puta tjedno (31\%), što govori o zanimanju ispitanika za dolazak u knjižnicu u vrlo teškim okolnostima (širenje koro- 
navirusa i ukidanje javnog prijevoza u središtu Zagreba kao posljedicu razornog potresa).

4. Ocijenite stupanj do kojeg su vam pojedine usluge knjižnice nedostajale u vrijeme dok je knjižnica bila zatvorena za korisnike (OZNAČITE KUĆICU UZ ODGOVARAJUĆI BROJ LJESTVICE OZNAKOM $1-5 ; 1=$ nisu uopće nedostajale, 5 = najviše su nedostajale) (MOGUĆE JE ZAOKRUŽITI VIŠE ODGOVORA).

Tablica 3. Koliko su korisnicima pojedine usluge knjižnice nedostajale u vrijeme dok je knjižnica bila zatvorena za korisnike $(\mathrm{N}=67)$

\begin{tabular}{|c|c|c|c|c|c|c|c|c|c|c|}
\hline & \multicolumn{2}{|c|}{5} & \multicolumn{2}{|r|}{4} & \multicolumn{2}{|r|}{3} & \multicolumn{2}{|r|}{2} & \multicolumn{2}{|r|}{1} \\
\hline & $\mathrm{N}$ & $\%$ & $\mathrm{~N}$ & $\%$ & $\mathrm{~N}$ & $\%$ & $\mathrm{~N}$ & $\%$ & $\mathrm{~N}$ & $\%$ \\
\hline Posudba knjiga & 35 & 52,24 & 11 & 16,42 & 8 & 11,94 & 4 & 5,97 & 9 & 13,43 \\
\hline $\begin{array}{l}\text { Informacijski upiti } \\
\text { knjižničarima }\end{array}$ & 9 & 13,43 & 6 & 8,96 & 15 & 22,39 & 8 & 11,94 & 27 & 40,3 \\
\hline $\begin{array}{l}\text { Upiti o novim } \\
\text { naslovima knjiga }\end{array}$ & 10 & 14,93 & 5 & 7,46 & 17 & 25,37 & 9 & 13,43 & 23 & 34,33 \\
\hline Tribine & 9 & 13,43 & 2 & 2,98 & 8 & 11,94 & 10 & 14,93 & 36 & 53,73 \\
\hline $\begin{array}{l}\text { Predstavljanja } \\
\text { knjiga }\end{array}$ & 8 & 11,94 & 3 & 4,48 & 6 & 8,96 & 12 & 17,91 & 36 & 53,73 \\
\hline $\begin{array}{l}\text { Pronalaženje lite- } \\
\text { rature za školova- } \\
\text { nje / studiranje }\end{array}$ & 13 & 19,40 & 15 & 22,39 & 11 & 16,41 & 5 & 7,46 & 19 & 28,36 \\
\hline $\begin{array}{l}\text { Boravak u knjiž- } \\
\text { nici bez obzira na } \\
\text { svrhu boravka }\end{array}$ & 21 & 31,34 & 9 & 13,43 & 9 & 13,43 & 8 & 11,94 & 15 & 22,39 \\
\hline $\begin{array}{l}\text { Komunikacija } \\
\text { s knjižničarima } \\
\text { općenito }\end{array}$ & 11 & 16,41 & 13 & 19,4 & 13 & 19,4 & 11 & 16,41 & 16 & 23,88 \\
\hline Učenje u knjižnici & 24 & 35,82 & 4 & 5,97 & 8 & 11,94 & 7 & 10,44 & 18 & 26,87 \\
\hline $\begin{array}{l}\text { Komunikacija s } \\
\text { drugim korisni- } \\
\text { cima }\end{array}$ & 5 & 7,46 & 3 & 4,48 & 12 & 17,91 & 10 & 14,93 & 32 & 47,76 \\
\hline $\begin{array}{l}\text { Čitanje novina i } \\
\text { časopisa }\end{array}$ & 2 & 2,99 & 0 & 0 & 10 & 14,93 & 10 & 14,93 & 39 & 58,21 \\
\hline
\end{tabular}

Prema rezultatima dobivenim od ispitanika u četvrtom pitanju (tablica 3) vidljive su razlike između vrste korisnika koji uz najpopularniju uslugu knjižnice - posudbu knjiga - imaju potrebu za boravkom u knjižnici, ali zbog različitih 
aktivnosti. Odgovori u tom pitanju sugeriraju potrebu (najčešće) studenata, koji su česti korisnici knjižnice, za boravkom u knjižnici radi učenja. Međutim, teško je interpretirati razloge velikih razlika među pojedinim odgovorima, tim više jer su prethodna istraživanja pokazala veliku popularnost događaja u knjižnicama poput tribina, predavanja, čitanja novina i časopisa, predstavljanja knjiga i sl. Dakako, potrebno je uzeti u obzir koronavirus zbog kojega su se promijenili prioriteti u životima korisnika knjižnice, ali je za potpuno razumijevanje dobivenih rezultata $\mathrm{u}$ četvrtom pitanju potrebno provesti intervju s korisnicima koji se u trenutku provedbe ankete nisu htjeli zadržavati duže vrijeme u prostoru knjižnice zbog aktualnih epidemioloških mjera, pa je time intervju postao neizvediv.

5. Koje ste online usluge Knjižnica grada Zagreba koristili (MOGUĆE JE ZAOKRUŽITI VIŠE ODGOVORA):

U ovom pitanju odgovori su podijeljeni u dvije grupe: a) usluge koje su korisnici mogli koristiti tijekom vremena u kojem je knjižnica bila zatvorena i b) usluge koje su korisnici mogli koristiti nakon ponovnog otvaranja knjižnice 27. 4. 2020.

a) Tijekom razdoblja u kojem je knjižnica bila zatvorena

Tablica 4. Usluge koje su korisnici koristili tijekom razdoblja u kojem je knjižnica bila zatvorena $(\mathrm{N}=64)$

\begin{tabular}{|l|l|l|}
\hline & N & $\%$ \\
\hline Kataloge knjižnica & 37 & 57,81 \\
\hline Radno vrijeme & 35 & 54,68 \\
\hline Informacije i upute za ulazak u knjižnicu & 27 & 42,19 \\
\hline Posudite $e$-knjigu & 18 & 28,13 \\
\hline Upute za posudbu knjiga & 11 & 17,19 \\
\hline Budite online - pitajte knjižničara & 10 & 15,62 \\
\hline Preporuke novih naslova knjiga & 9 & 14,06 \\
\hline Virtualne izložbe & 4 & 6,25 \\
\hline Slanje upita o građi & 3 & 4,69 \\
\hline Učlanjenje u knjižnicu & 3 & 4,69 \\
\hline Rezervacija građe & 1 & 1,56 \\
\hline Zvučne knjige za slijepe i slabovidne & 1 & 1,56 \\
\hline Nešto drugo, što ovdje nije navedeno & 1 & 1,56 \\
\hline Kalendar godišnjica & 0 & 0 \\
\hline
\end{tabular}

U prvom dijelu petog pitanja odgovori (tablica 4) su se u najvećoj mjeri odnosili na pribavljanje informacija o građi, a to su u preko polovice odgovora bili pre- 
traživanje kataloga Knjižnica grada Zagreba $(57,81 \%)$, radno vrijeme knjižnice $(54,68 \%)$ te, u nešto manjem postotku, informacije i upute za ulazak u knjižnicu $(42,19 \%)$. Svi odgovori ponuđeni ispitanicima predstavljaju stvarne usluge sustava Knjižnica grada Zagreba dostupne tijekom razdoblja kada su knjižnice bile zatvorene. Nakon tri najčešće odabrana rezultata, slijedi posudba $e$-knjiga $(28,13$ \%), usluga dostupna od kraja svibnja 2019. godine, a u vrijeme pandemije koronavirusa osobito atraktivna korisnicima koji su ujedno i članovi knjižnice jer je knjižnica bila zatvorena za sve kategorije korisnika (i članove knjižnice i one koji to nisu). Preostale usluge ispitanici su koristili bitno manje.

b) Nakon njezina ponovnog otvaranja

Tablica 5. Usluge koje su korisnici koristili nakon ponovnog otvaranja knjižnice 27. 4. 2020. $(\mathrm{N}=64)$

\begin{tabular}{|l|l|l|}
\hline & $\mathrm{N}$ & $\%$ \\
\hline Radno vrijeme & 40 & 62,5 \\
\hline Kataloge knjižnica & 35 & 54,69 \\
\hline Informacije i upute za ulazak u knjižnicu & 23 & 35,94 \\
\hline Rezervaciju građe & 18 & 28,13 \\
\hline Preporuke novih naslova knjiga & 13 & 20,31 \\
\hline Slanje upita o građi & 12 & 18,75 \\
\hline Upute za posudbu knjiga & 10 & 15,63 \\
\hline Posudite $e$-knjigu & 9 & 14,06 \\
\hline Budite online - pitajte knjižničara & 5 & 7,81 \\
\hline Učlanjenje u knjižnici & 4 & 6,25 \\
\hline Virtualne izložbe & 2 & 3,13 \\
\hline Nešto drugo, što ovdje nije navedeno & 1 & 1,56 \\
\hline Kalendar godišnjica & 0 & 0 \\
\hline Zvučne knjige za slijepe i slabovidne & 0 & 0 \\
\hline
\end{tabular}

U drugom dijelu petog pitanja (tablica 5) odgovori su također ponuđeni u skladu sa stvarnom ponudom usluga sustava Knjižnica grada Zagreba. Prva tri odgovora zastupljena u tablici 4, najzastupljeniji su i u tablici 5 (premda drugim redoslijedom, jer je dolazak u knjižnicu ponovno postao moguć kad je prostor pregledan nakon potresa 22. 3. 2020.), pa je na prvom mjestu radno vrijeme $(62,5 \%)$, zatim pretraživanje kataloga knjižnica $(54,69 \%)$ i informacije i upute za ulazak u knjižnicu $(35,94 \%)$. U ovoj grupi pitanja posudba $e$-knjiga zastupljena je bitno manje $(14,06 \%$ ) (zanimanje ispitanika prepolovilo se, tablica 
4). Ponovno su postale aktualne usluge poput rezervacije građe $(28,13 \%)$, preporuka novih naslova knjiga $(20,31 \%)$ i slanja upita o građi $(18,75 \%)$. Bilo bi pogrešno zaključiti kako je ponovnim otvaranjem knjižnice nestalo zanimanje za $e$-knjigu, dugo iščekivanu uslugu pokrenutu u 2019. godini, međutim, istraživanja provedena u ovoj knjižnici provedena tijekom 10 godina pokazala su da je posudba tiskane građe kontinuirano najtraženija usluga knjižnice, što je moguće povezati i s odgovorima u tablici 5 o uslugama pretraživanja kataloga knjižnice, rezervacije građe, preporuka novih naslova knjiga, slanja upita o građi te uputa za posudbu knjiga.

6. Koje ste digitalne informacijske izvore Knjižnica grada Zagreba koristili (MOGUĆE JE ZAOKRUŽITI VIŠE ODGOVORA):

a) Tijekom razdoblja u kojem je knjižnica bila zatvorena

Tablica 6. Korištenje digitalnih informacijskih izvora Knjižnica grada Zagreba tijekom razdoblja kada je knjižnica bila zatvorena $(\mathrm{N}=55)$

\begin{tabular}{|l|l|l|}
\hline & $\mathrm{N}$ & $\%$ \\
\hline$E$-knjige u ponudi Knjižnica grada Zagreba & 23 & 41,82 \\
\hline Besplatne $e$-knjige & 20 & 36,36 \\
\hline Digitalne zbirke Knjižnica grada Zagreba & 12 & 21,82 \\
\hline
\end{tabular}

Odgovore u šestom pitanju (tablica 6) dali su korisnici knjižnice koji su se u vrijeme provedbe istraživanja nalazili u prostoru knjižnice te njihov broj (i njihovi odgovori) predstavljaju samo dio ukupnog broja korisnika koji su koristili usluge sustava Knjižnica grada Zagreba u vrijeme kada su knjižnice bile zatvorene. Prikupljeni odgovori važni su jer doprinose stvaranju cjelovite slike o korištenju e-građe u pojedinim narodnim knjižnicama u Republici Hrvatskoj, o čemu još ne postoje potpuni podaci, te je potrebno provesti dodatna istraživanja među svim korisnicima sustava Knjižnice grada Zagreba, onih koji dolaze u knjižnice i onih koji koriste online-usluge (isključivo ili u kombinaciji s uslugama koje su dostupne isključivo u prostorima knjižnica navedenog sustava). Ispitanici koji su sudjelovali u ovom istraživanju također su tijekom razdoblja u kojem je knjižnica bila zatvorena koristili $e$-građu i to najviše $e$-knjige u ponudi Knjižnica grada Zagreba $(41,82 \%)$, potom besplatne knjige na internetu $(36,36 \%)$ i digitalne zbirke Knjižnica grada Zagreba (21,82 \%). 
b) Nakon njezina ponovnog otvaranja

Tablica 7. Korištenje digitalnih informacijskih izvora Knjižnica grada Zagreba nakon njezina ponovnog otvaranja $(\mathrm{N}=21)$

\begin{tabular}{|l|l|l|}
\hline & $\mathrm{N}$ & $\%$ \\
\hline$E$-knjige u ponudi Knjižnica grada Zagreba & 12 & 46,15 \\
\hline Besplatne $e$-knjige & 9 & 34,62 \\
\hline Digitalne zbirke Knjižnica grada Zagreba & 5 & 19,23 \\
\hline
\end{tabular}

U odnosu na vrijeme tijekom kojeg je knjižnica bila zatvorena, nakon njezina ponovnog otvaranja zanimanje za $e$-građu među ispitanicima značajno je opalo (pitanje 5b). U drugom dijelu šestog pitanja, koji se odnosio na korištenje digitalnih informacijskih izvora (tablica 7) nakon ponovnog otvaranja knjižnice, vidljiv je znatno manji odaziv ispitanika. Među njihovim odgovorima i dalje su najzastupljenije $e$-knjige u ponudi Knjižnica grada Zagreba (46,15\%), potom slijede besplatne $e$-knjige na internetu (34,62 \%) te na kraju digitalne zbirke Knjižnica grada Zagreba (19,23 \%). Međutim, od rezultata istraživanja važnija je činjenica da su $e$-knjige postale dijelom ponude sustava Knjižnica grada Zagreba, što korisnicima jamči dolazak do tražene građe u tiskanom i digitalnom obliku (pri čemu je fond $\mathrm{u}$ digitalnom obliku brojem manji u odnosu na tiskani fond). I u tom su slučaju potrebna dodatna istraživanja o zadovoljstvu ponudom naslova $e$-knjiga, dostupnosti naslova (što ovisi o ugovoru s nakladnicima) i tehničkim uvjetima korištenja $e$-knjiga.

7. Nakon ponovnog otvaranja knjižnice, koju vrstu knjižnične građe biste radije nastavili koristiti (OZNAČITE JEDAN ODGOVOR)?

Tablica 8. Vrsta knjižnične građe koju bi korisnici radije nastavili koristiti nakon ponovnog otvaranja knjižnice $(\mathrm{N}=69)$

\begin{tabular}{|l|l|l|}
\hline & $\mathrm{N}$ & $\%$ \\
\hline Tiskanu/papirnatu & 47 & 68,12 \\
\hline Obje podjednako & 20 & 28,99 \\
\hline Ne mogu odlučiti & 2 & 2,89 \\
\hline Digitalnu & 0 & 0 \\
\hline
\end{tabular}

U prethodnom pitanju očigledan je manji broj ispitanika koji su odgovorili na vrlo važna pitanja. S obzirom na ponovno otvaranje knjižnica javnosti, tj. korisnicima, u ovom se pitanju htjelo saznati koju bi vrstu građe korisnici knjižnica radije 
nastavili koristiti. Ispitanici su ukazali na izbor ponajviše tiskane/papirnate građe $(68,12 \%)$ (tablica 8$)$ koji bi rado nastavili koristiti nakon ponovnog otvaranja knjižnice, dok se nitko nije odlučio dati prednost digitalnoj građi. Međutim, dio ispitanika odlučio se za podjednako korištenje tiskane/papirnate i digitalne građe $(28,99 \%)$, te mali dio ispitanika nije mogao odlučiti $(2,89 \%)$.

8. Smatrate li da bi knjižnica u neposrednoj budućnosti trebala osigurati više građe i usluga u digitalnom obliku (OZNAČITE JEDAN ODGOVOR)?

Tablica 9. Vrsta građe i usluga koju bi knjižnica trebala imati u većem broju

\begin{tabular}{|l|l|c|c|c|c|c|}
\hline & \multicolumn{2}{|c|}{$\mathrm{Da}$} & \multicolumn{3}{c|}{$\mathrm{Ne}$} & \multicolumn{2}{c|}{ Ne mogu odlučiti } \\
\cline { 2 - 7 } & $\mathrm{N}$ & $\%$ & $\mathrm{~N}$ & $\%$ & $\mathrm{~N}$ & $\%$ \\
\hline $\begin{array}{l}\text { Trebala imati više GRAĐE u } \\
\text { digitalnom obliku? (N = 69) }\end{array}$ & 35 & 50,72 & 16 & 23,19 & 18 & 26,09 \\
\hline $\begin{array}{l}\text { Trebala imati više USLUGA u } \\
\text { digitalnom obliku? (N = 64) }\end{array}$ & 31 & 48,43 & 11 & 17,19 & 22 & 34,38 \\
\hline
\end{tabular}

Za razliku od isticanja osobnih preferencija za korištenjem tiskane/papirnate, odnosno, digitalne građe, u ovom su pitanju ispitanici mogli iskazati stav o razvoju fonda knjižnice u neposrednoj budućnosti. Napominjemo kako je riječ o ispitanicima koji su na pitanja odgovarali u prostoru knjižnice, pa su i njihovi odgovori (tablica 9) usmjereni više prema potrebi za tiskanom građom u knjižnici (50,72 \%) u odnosu na digitalnu građu (48,43\%), koju također žele vidjeti u ponudi knjižnice u većim količinama. U slučaju digitalne građe bilo je nešto više neodlučnih ispitanika u odnosu na ispitanike koji nisu mogli odlučiti za tiskanu građu $(34,38$ $\%$ prema $26,09 \%$ ).

9. Prema vašem mišljenju, imaju li izvanredne situacije poput epidemije koronavirusa utjecaja na vaš odnos prema knjižnici (OZNAČITE KUĆICU UZ ODGOVARAJUĆI BROJ LJESTVICE OZNAKOM 1 - 5; 1 = uopće nema utjecaja; 5 = ima velik utjecaj)?

Tablica 10. Utjecaj izvanrednih situacija poput epidemije koronavirusa na odnos korisnika prema knjižnici $(\mathrm{N}=65)$

\begin{tabular}{|l|l|l|l|l|l|l|l|l|l|l|}
\hline & \multicolumn{3}{|l}{} & \multicolumn{2}{l|}{2} & \multicolumn{3}{l|}{3} & \multicolumn{3}{l|}{4} & \multicolumn{2}{l|}{5} \\
\hline & $\mathrm{N}$ & $\%$ & $\mathrm{~N}$ & $\%$ & $\mathrm{~N}$ & $\%$ & $\mathrm{~N}$ & $\%$ & $\mathrm{~N}$ & $\%$ \\
\hline Pozitivan utjecaj & 28 & 43,08 & 5 & 7,69 & 19 & 29,23 & 10 & 15,38 & 3 & 4,62 \\
\hline Negativan utjecaj & 34 & 52,30 & 9 & 13,85 & 17 & 26,25 & 3 & 4,61 & 2 & 3,08 \\
\hline
\end{tabular}


U ovom pitanju analizirao se stav ispitanika o odnosu prema knjižnici u izvanrednoj situaciji. Ispitanici su u oba dijela pitanja najviše birali odgovore koji označavaju da izvanredne situacije nemaju niti pozitivan $(43,08 \%)$ niti negativan $(52,30 \%)$ utjecaj na odnos prema knjižnici (tablica 10). S obzirom na to da su ispitanici osobe koje su svojim dolaskom potvrdile da im izvanredna situacija pokrenuta epidemijom koronavirusa nije promijenila naviku dolaska u knjižnicu, rezultati u kategoriji odgovora - „1 = uopće nema utjecaja“ su to potvrdili u objema kategorijama u otprilike polovini slučajeva. Dio ispitanika u kategoriji 3 koja se nalazi na pola puta također je dao svoj odgovor u nešto većem broju $(29,23 \%$ i $26,25 \%$ ), te sugeriraju da je izvanredna situacija ipak imala određeni pozitivni utjecaj, odnosno, negativni utjecaj na njihov odnos prema knjižnici. Promatrajući ostale odgovore, može se zaključiti kako je za vrlo malen broj ispitanika izvanredna situacija značila velik pozitivni (4,62 \%), odnosno, negativni (3,08 \%) utjecaj na odnos prema knjižnici u kojoj su se nalazili u vrijeme provedbe istraživanja.

10. Ocijenite važnost knjižnice za pojedini segment vlastitog života (OZNAČITE KUĆICU UZ ODGOVARAJUĆI BROJ LJESTVICE OZNAKOM 1 = u potpunosti nevažna do $5=$ u potpunosti važna):

Tablica 11. Važnost knjižnice za pojedine segmente života korisnika

\begin{tabular}{|l|c|c|c|c|c|c|c|c|c|c|}
\hline & \multicolumn{2}{|c|}{1} & \multicolumn{2}{|c|}{2} & \multicolumn{3}{|c|}{3} & \multicolumn{2}{|c|}{4} & \multicolumn{2}{|c|}{5} \\
\hline & $\mathrm{N}$ & $\%$ & $\mathrm{~N}$ & $\%$ & $\mathrm{~N}$ & $\%$ & $\mathrm{~N}$ & $\%$ & $\mathrm{~N}$ & $\%$ \\
\hline $\begin{array}{l}\text { poslovni život } \\
(\mathrm{N}=64)\end{array}$ & 19 & 29,69 & 6 & 9,38 & 12 & 18,75 & 7 & 10,94 & 20 & 31,25 \\
\hline $\begin{array}{l}\text { obrazovanje } \\
(\mathrm{N}=66)\end{array}$ & 3 & 4,55 & 0 & 0 & 10 & 15,15 & 14 & 21,21 & 39 & 59,09 \\
\hline $\begin{array}{l}\text { slobodno vrijeme } \\
(\mathrm{N}=68)\end{array}$ & 4 & 5,88 & 6 & 8,82 & 7 & 10,29 & 20 & 29,41 & 31 & 45,59 \\
\hline $\begin{array}{l}\text { upoznavanje drugih } \\
\text { ljudi (N = 64) }\end{array}$ & 26 & 40,63 & 16 & 25 & 13 & 20,31 & 3 & 4,69 & 6 & 9,38 \\
\hline $\begin{array}{l}\text { upoznavanje s novim } \\
\text { idejama (N = 64) }\end{array}$ & 9 & 14,06 & 9 & 14,06 & 17 & 26,56 & 11 & 17,19 & 18 & 28,13 \\
\hline
\end{tabular}

Prikazani odgovori (tablica 11) odnose se na utjecaj knjižnice na pojedine segmente života korisnika. Prema dobivenim odgovorima knjižnica ima najveći utjecaj na poslovni život korisnika, potom na njihovo obrazovanje, slobodno vrijeme i upoznavanje s novima idejama, dok najmanji utjecaj ima na upoznavanje drugih ljudi. Raspodjela odgovora nije potpuno ujednačena, pa je utjecaj knjižnica veći na obrazovanje i slobodno vrijeme, u odnosu na poslovni život i upoznavanje s novim idejama (čemu knjižnice također služe, a što je i naglašeno u uvodnom dijelu rada). 


\section{Diskusija}

U ovom radu provedeno je istraživanje korisnika koji su boravili u knjižnici bez obzira na nepovoljne epidemiološke uvjete u gradu Zagrebu i posljedice potresa. Svoj pozitivan odnos i želju za dolaskom u prostor Knjižnice i čitaonice Bogdana Ogrizovića potvrdile su dvije trećine ispitanika, koji su unatoč objektivnim problemima došli u prostor knjižnice. Odluka o dolasku u knjižnicu ovisila je izravno o epidemiološkoj situaciji i propisanim mjerama zaštite zdravlja te činjenici da je samo središte grada u trenutku ponovnog otvaranja knjižnice za korisnike bilo prometno izolirano i nesigurno zbog oštećenja na zgradama. No polovicu ispitanika ti problemi nisu odvratili od jednako čestog dolaska u knjižnicu kao i prije pandemije koronavirusa i potresa. To su sami potvrdili iskazivanjem namjere dolaska u knjižnicu, što pokazuje vrlo visok stupanj zainteresiranost za knjižnicu. Tijekom razdoblja kada su knjižnice bile zatvorene za dolazak korisnika, korisnicima su najviše nedostajale usluge posudbe, boravak u knjižnici bez obzira na razlog i učenje u knjižnici, a zanimljivo je kako im nisu nedostajale neke popularne usluge poput tribina, predstavljanja knjiga i sl., koje su inače zaštitni znak Knjižnice i čitaonice Bogdana Ogrizovića. Tijekom tog razdoblja korisnici su nastavali koristiti usluge pretraživanja informacijskih izvora poput kataloga knjižnica, a uočeno je i veće zanimanje za $e$-knjigu, ali nakon ponovnog otvaranja prostora knjižnice, interes korisnika ponovno je bio usmjeren ka uslugama povezanima s papirnatom građom. Takav se rezultat može interpretirati kao želja za osobnijim i neposrednim pristupom knjižnici kao prostoru i građi koju nudi, a što udaljeni pristup putem interneta ne može ostvariti. Oko pitanja digitalnih i nedigitalnih usluga u knjižnicama vode se brojne rasprave, a ovo je istraživanje izravno ukazalo na želju korisnika za dolaskom u stvarnu umjesto virtualne knjižnice. Uočeno je i povećano korištenje digitalnih informacijskih izvora Knjižnica grada Zagreba s naglaskom na novoj usluzi (iz 2019. godine) posudbi $e$-knjiga, čije je korištenje ipak opalo nakon ponovnog otvaranja knjižnice, kada su korisnici ponovno iskazali želju za korištenjem papirnate građu uz dopunu ponude digitalnom građom (dakle, podjednako obje vrste građe), dok su izričito odlučili kako ne žele isključivo povećanje digitalne građe. Iz tih rezultata možemo iščitati tradicionalan odnos korisnika prema knjižnici kao fizičkom prostoru s fizičkom građom. Dopuna tog odnosa digitalnom građom dobrodošla je, međutim, kada je riječ o građi, prednost ima papirnata. Prvi svršetku upitnika, ispitanici i korisnici knjižnice imali su priliku ocijeniti utjecaj izvanrednih situacija poput epidemije koronavirusa na njihov odnos prema knjižnici. Iskazali su nešto veći negativan utjecaj, što je s obzirom na ekstremnu situaciju posve očekivano. Korisnici su iskazali i pozitivan odnos gotovo jednak negativnom, što znači neodricanje od knjižnice i usluga koje ona nudi. Za kraj su ispitanici potvrdili kako im je knjižnica i dalje važna u trima segmentima: poslovnom životu, obrazovanju i za njihovo slobodno vrijeme. Sveukupno, rezultati su pokazali kako su dvije ekstremne situacije, koronavirus te ra- 
zorni potres, imali utjecaj na korištenje knjižnice jer su za to postojale objektivne i nepromjenjive okolnosti. U najtežim trenucima za knjižnicu, u ožujku i travnju 2020. godine, korisnici nisu odustali od korištenja usluga knjižnice te su nastavili koristiti građu koju su u tom trenutku imali već posuđenu, kao i online-usluge i građu dostupnu na internetu. Time je potvrđena i glavna hipoteza istraživanja o nastavku korištenja usluga i građe knjižnice u kriznim situacijama te stabilnom odnosu korisnika i knjižnice. Za knjižnicu je situacija poput ove iznimno velik test u kojem se uspješno snašla, što su korisnici prepoznali povratkom u njezine prostore nakon otvaranja, što je zabilježeno u medijima fotografijama na kojima je bilo moguće vidjeti red korisnika ispred knjižnice, što je najbolji dokaz interesa korisnika za Knjižnicu i čitaonicu Bogdana Ogrizovića.

\section{Zaključak}

Uloga knjižnice u modernom, digitaliziranom društvu iznova se preispituje u povoljnim i manje povoljnim uvjetima za njihov rad. Sve je to iscrpno opisano u literaturi u kojoj se spominju financijeri rada knjižnica diljem svijeta koji nisu uvijek uvjereni u opravdanost financiranja knjižnica, što nažalost dovodi do njihova zatvaranja, što je bio čest slučaj u Velikoj Britaniji i Sjedinjenim Američkim Državama od 2008. godine i tijekom posljednje velike ekonomske krize. Osim problema financijske prirode, knjižnice trpe posljedice prirodnih nepogoda i bolesti svojih korisnika i zaposlenika. U Hrvatskoj se uz još uvijek aktualnu pandemiju koronavirusa u Zagrebu dogodio i razorni potres. Mnoge knjižnice (bez obzira na vrstu) nisu ponovno otvorile svoja vrata nakon potresa zbog potrebe za sanacijom prostora, kao i zbog zabrane rada u ožujku i travnju 2020. godine zbog pandemije koronavirusa. Knjižnica i čitaonica Bogdana Ogrizovića nastavila je s radom u ograničenim epidemijskim uvjetima te nije pretrpjela znatniju štetu od potresa. U takvim uvjetima korisnici su nastavili koristiti građu koju su već imali posuđenu, kao i $e$-knjige dostupne putem sustava Knjižnica grada Zagreba. Povratkom korisnika u prostor knjižnice, ona se nije u potpunosti vratila svakodnevnim brojnim aktivnostima zbog epidemioloških mjera koje traju i 6 mjeseci nakon prvih donesenih mjera. Time je knjižnici otežan rad, a nastavljaju se provoditi samo neke aktivnosti. Bez obzira na težinu situacije, provedeno istraživanje korisnika pokazalo je da su korisnici sada već tradicionalno vjerni knjižnici te da su se poput same knjižnice uspješno prilagodili neočekivanim situacijama koje su se dogodile u proljeće 2020. i nastavile tijekom cijele godine. 


\section{LITERATURA}

Aabø, S. Are public libraries worth their price? A contingent valuation study of Norwegian public libraries. // New Library World 106, 1218/1219(2005), 487-495.

Aabø, S. The role and value of public libraries in the age of digital technologies. // Journal of Librarianship and Information Science 37, 4(2005), 205-211.

Alajmi, B. M.; D. Albudaiwi. Response to COVID-19 pandemic: Where do public libraries stand? // Public Library Quarterly. 2020. DOI: https://doi.org/10.1080/0161 6846.2020.1827618.

Altay, A.; A. Tekin; B. Dursun; M. Yayla. The role of the libraries in the information society. 2012. [citirano: 2020-05-01]. Dostupno na: http://hdl.handle. net/20.500.11857/131.

Audunson, R. The public library as a meeting-place in a multicultural and digital context: the necessity of low-intensive meeting-places. // Journal of Documentation 61, 3(2005), 429-441.

Audunson, R.; S. Aabø; R. Blomgren; H. C. Hobohm; H. Jochumsen; M. Khosrowjerdi; R. Mumenthaler i suradnici. Public libraries as public sphere institutions: a comparative study of perceptions of the public library's role in six European countries. // Journal of Documentation 75, 6(2019), 1396-1415.

Baker, D.; W. Evans. Libraries and society: role, responsibility and future in an age of change. Oxford: Chandos Publishing, 2011.

Biando E. J.; M. S. Rauseo; K. R. Unge. Community centered: 23 reasons why your library is the most important place in town. // Public Libraries Online. 2013. [citirano: 2020-05-01]. Dostupno na: http://publiclibrariesonline.org/2013/04/communitycentered-23-reasons-why-your-library-is-the-most-important-place-in-town/.

Freeman, G.T. The library as place: changes in learning patterns, collections, technology, and use. // library as place: rethinking roles, rethinking space. council on library and information resources. Washington, D.C.: Council on Library and Information Resources, 2005. Str. 1-9 [citirano: 2020-05-01]. Dostupno na: https://www. clir.org/wp-content/uploads/sites/6/pub129.pdf.

Garmer, A.K. Public libraries in the community. // I/S A Journal of Law and Policy for the Information Society, 2016. [citirano: 2020-05-01]. Dostupno na: https://kb.osu. edu/bitstream/handle/1811/81147/ISJLP_V13N1_001.pdf.

Geiger, A.W. Millennials are the most likely generation of Americans to use public libraries. // Pew Research Center. 2017. [citirano: 2020-05-01]. Dostupno na: https:// www.pewresearch.org/fact-tank/2017/06/21/millennials-are-the-most-likely-generation-of-americans-to-use-public-libraries/.

Goulding, A. Engaging with community engagement: public libraries and citizen involvement. // New Library World 110, 1-2(2009), 37-51. 
HZJZ objavio upute za korištenje knjižnica i antikvarijata. [citirano: 2020-10-01]. Dostupno na: https://ezadar.net.hr/kultura/3805627/hzjz-objavio-upute-za-koristenje-knjiznica-i-antikvarijata/.

Izvještaj o radu Knjižnica grada Zagreba za 2019. godinu. Zagreb: Knjižnice grada Zagreba, 2020. [citirano: 2021-02-24]. Dostupno na: https://issuu.com/knjinicegradazagreba/docs/izvje_taj_za_uv_2019.

Jochumsen, H.; C.H. Rasmussen; D. Skot-Hansen. The four spaces - a new model for the public library. // New Library World 113, 11-12(2012), 586-597.

Johnson, C. A. Do public libraries contribute to social capital? A preliminary investigation into the relationship. // Library \& Information Science Research 32(2010), 147-155.

Johnston, C. Electronic technology and its impact on libraries, // Journal of librarianship and information science 30, 1(1998), 7-24. [citirano: 2020-05-01]. Dostupno i na: http://citeseerx.ist.psu.edu/viewdoc/download?doi=10.1.1.870.3629\&rep=rep1\&type $=$ pdf.

Kaser Corsillo, G. COVID-19: the impact on public libraries. // Public Libraries Online. 2020. DOI: https://doi.org/10.1080/01616846.2020.1827618.

Kerslake, E.; M. Kinnell. Public libraries, public interest and the information society: theoretical issues in the social impact of public libraries. // Journal of Librarianship and Information Science 30, 3(1998), 159-167.

Knjižnice grada Zagreba. Događanja. [citirano: 2020-06-01]. Dostupno na: http://www. $\mathrm{kgz} . \mathrm{hr} / \mathrm{hr} /$ dogadjanja $/ 10$ ?page $=7 \&$ datumod $=01.03 .2020 \&$ datumdo $=30.04 .2020$ ).

Knjižnice grada Zagreba. Novo radno vrijeme Knjižnica grada Zagreba od 27. travnja 2020. [citirano: 2020-05-01]. Dostupno na: http://www.kgz.hr/hr/dogadjanja/natjecanje-u-citanju-naglas-54461/novosti/novo-radno-vrijeme-knjiznica-grada-zagreba-od-27-travnja-2020/53332.

Library closures around the world. [citirano: 2021-01-24]. Dostupno na: https://www. ifla.org/covid-19-and-libraries\#closures.

Libraries in the pandemic: evolving services to meet local need. // Libraries Connected. [citirano: 2021-01-24]. Dostupno na: https://www.librariesconnected.org.uk/resource/libraries-pandemic-evolving-services-meet-local-need.

Mainka, A.; S. Hartmann; L. Orszullok; I. Peters; A. Stallmann; W. G. Stock. Public libraries in the knowledge society: core services of libraries in informational world cities. // Libri 6, 4(2013), 295-319.

Pauček Šljivak, M. Krenulo je popuštanje mjera, Zagrepčani okupirali dućane: „Ljudi su željni svega“. // Indeks.hr. 2020. [citirano: 2020-05-01]. Dostupno na: https:// www.index.hr/vijesti/clanak/krenulo-je-popustanje-mjera-zagrepcani-okupirali-ducane-ljudi-su-zeljni-svega/2178444.aspx.

Pareek, N.; A. Gangrade. Role of the libraries as information resources in globalization. // International Journal of Librarianship and Administration 7, 1(2016), 13-23. 
Role of libraries and information centres in modern society. // Development of libraries and their role in society. 2017. [citirano: 2020-05-01]. Dostupno na: http://egyankosh.ac.in/handle/123456789/33044.

Rooney-Browne, C.; D. McMenemy. Public libraries as impartial spaces in a consumer society: possible, plausible, desirable? // New Library World 111, 11/12(2010), 455-467.

Scott, R. The role of public libraries in community building. // Public Library Quarterly 30, 3(2011), 191-227.

[Sedamdeset] 70 godina Knjižnice i čitaonice Bogdana Ogrizovića. [citirano: 202102-24]. Dostupno na: http://fama.com.hr/70-godina-knjiznice-i-citaonice-bogdana-ogrizovica/.

Uddin, J.; N. Hasan. Use of information technology in library service: a study on some selected libraries in northern part of Bangladesh. // International Journal of Library and Information Science 4, 3(2012), 34-44.

Tait, E.; K. Martzoukou; P. Reid. Libraries for the future: the role of IT utilities in the transformation of academic libraries. // Palgrave Communication 2, 16070(2016). DOI: https://doi.org/10.1057/palcomms.2016.70.

Taylor, M.; M. E. Pratt; R. A. Fabes. Public libraries as a context for the study of learning and development. // Journal of Higher Education Outreach and Engagement 23, 2(2019), 51-62.

The intrinsic value of libraries as public spaces: technology and digital services reflect the changing role of libraries. Civica Group Limited, 2016. [citirano: 2020-0501]. Dostupno na: https:/www.uts.edu.au/sites/default/files/Civica+Intrinsic+value + of + libraries+report.pdf.

Tri dana izolacije: evo kako knjige koje ste vratili u knjižnicu provode vrijeme u karanteni. [citirano: 2020-10-01]. Dostupno na: https://www.sibenik.in/sibenik/tri-dana-izolacije-evo-kako-knjige-koje-ste-vratili-u-knjiznicu-provode-vrijeme-u-karanteni/122088.

Vårheim, A.; S. Steinmo; E. Ide. Do libraries matter? Public libraries and the creation of social capital. // Journal of Documentation 64, 6(2008), 877-892.

Webb, S. M. The role of public libraries in society: a case study from a poor suburb of Windhoek, Namibia, 2010. [citirano: 2020-05-01]. Dostupno na: http://hdl.handle. net/2142/14996.

Wenborn, C. How technology is changing the future of libraries. // The Wiley Network. 2018. [citirano: 2020-05-01]. Dostupno na: https://www.wiley.com/network/librarians/library-impact/how-technology-is-changing-the-future-of-libraries.

White, B. Guaranteeing access to knowledge: the role of libraries. // WIPO Magazine, 4 (2012). [citirano: 2020-05-01]. Dostupno na: https://www.wipo.int/wipo_magazine/ en/2012/04/article_0004.html.

Widdersheim, M. M.; M. Koizumi. Conceptual modelling of the public sphere in public libraries. // Journal of Documentation 72, 3(2016), 591-610. 